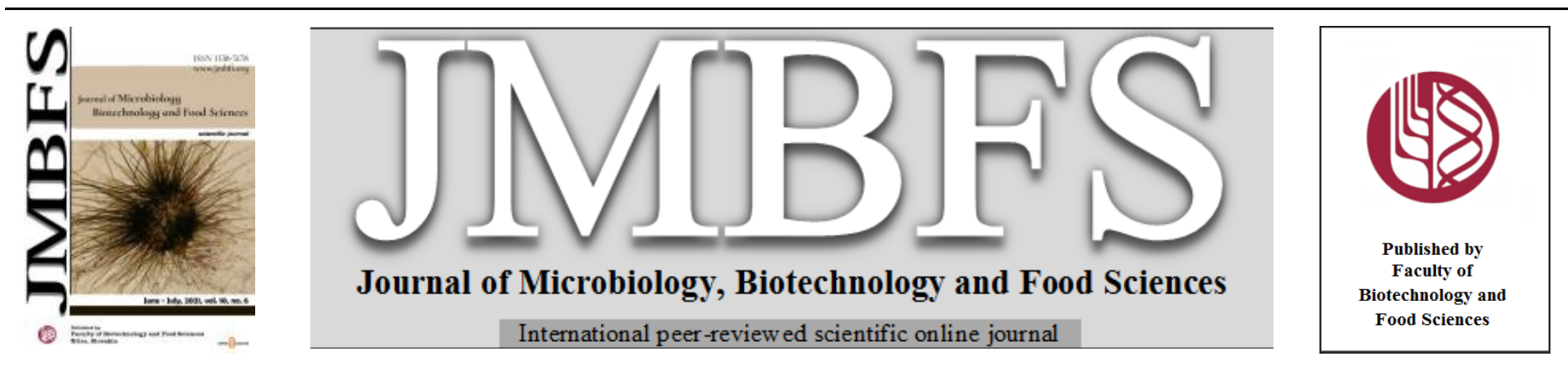

\title{
MIGRATION OF MICROELEMENTS AND HEAVY METALS IN THE SYSTEM «SOIL - PLANT - PLANT-BASED PRODUCTS»
}

\author{
Marina Senchenko $*^{1}$, Marina Stepanova ${ }^{2}$, Vera Pozdnyakova ${ }^{1}$,Elena Olenchuk ${ }^{3}$ \\ Address(es): Marina Senchenko, \\ ${ }^{1}$ Department of Technology of production and processing of agricultural products, Technological Faculty of FSBEI HE Yaroslavl SAA, Yaroslavl, Russia, phone \\ number: +7-910-975-19-28. \\ ${ }^{2}$ Department of Veterinary-sanitary expertise, Technological Faculty of FSBEI HE Yaroslavl SAA, Yaroslavl, Russia, phone number: +7-951-282-14-63. \\ ${ }^{3}$ Faculty of Veterinary Medicine and Zootechny of FSBEI HE Kostroma SAA, Kostroma, Russia, phone number: +7-953-642-84-69.
}

*Corresponding author: senchenko@yarcx.ru

https://doi.org/10.15414/jmbfs.3169

ARTICLE INFO

Received 22. 5. 2020

Revised 3. 1. 2021

Accepted 20. 1.2021

Published 1. 6. 2021

Regular article

open $\mathcal{O}_{\text {ACCESS }}$

\begin{abstract}
In Russia, raw materials of plant origin are used in the production of national beverages and food products. Many plots for the cultivated crops are located near urbanized areas, oil refineries, and machine-building plants. The research focuses on determining the concentration of heavy metals in soil in urbanized and rural areas. The content and transition of heavy metals to rhubarb and its processed product - kvass produced by various technologies have been identified as well. The purpose of this study is to determine the content of certain trace elements and heavy metals in soil, rhubarb, and its processed product - kvass made in different ways. The level of copper and lead in soil in rural areas has been found to be considerably higher than in the city. The concentration of cadmium and zinc is higher in the urbanized area. In the soils of rural and urbanized areas, the concentration of all the metals studied is sure to be higher than in the background levels. This indicates that soil contamination is caused not only by natural presence of elements but anthropogenic pollution as well. In analysis of transition and character of trace element accumulation in a soil-plant system, there is a strong link between the level of $\mathrm{Pb}, \mathrm{Cd}$ in the soil and a plant $(\mathrm{r}=0.81$ and 0.71 ; respectively). In analysis of transition and character of trace element accumulation in a soil-plant system, there is a strong link between the level of $\mathrm{Pb}, \mathrm{Cd}$ in the soil and a plant $(\mathrm{r}=0.81$ and 0.71; respectively). In the course of the study we found a symbateness between the content of trace elements in the soil and rhubarb: a reliable very strong, close to functional, direct link between the level of $\mathrm{Zn}, \mathrm{Pb}$ and $\mathrm{Cu}(\mathrm{r}=0.97 ; 0.90$ and 0.67 , respectively; at $\mathrm{p}<0.05)$. When studying the cross-environments transition of trace elements from soil to plants, a significant direct weak bond was established only for $\mathrm{Cu}(\mathrm{r}=0.31), \mathrm{Zn}(\mathrm{r}=0.33)$ and $\mathrm{Pb}(\mathrm{r}=0.35)$. In the raw material-product system, there is a reliable symbateness between the level of metal in kvass and the concentration in vegetable crops in terms of $\mathrm{Zn}(\mathrm{r}=0.32), \mathrm{Cu}(\mathrm{r}=0.46)$ and $\mathrm{Cd}(\mathrm{r}=0.38)$. No other reliably significant links have been established. Plant material produced according to organic production principles and the processing technology we've developed contribute to both the least impact on its constituent parts and the increased macro- and microelements content, the content of toxic elements remaining within the limits of the existing regulatory documents.
\end{abstract}

Keywords: heavy metals, toxicants, deposition media, inter-environment transition, kvass, functional ingredients, rhubarb, sweetener, organoleptic characteristics, macronutrients, trace elements

\section{INTRODUCTION}

With the growth of man-made impact on the environment, the content of dangerous compounds including heavy metals in veterinary supervision objects has increased. This issue has been studied for a long time and in general the mechanisms of biogeochemical behavior are clear, however, there is no consensus on the maximum permissible content of them in different types of soils yet. Heavy metals accumulate in the food chain and may become toxic to humans. Therefore, the study of the content of macro- and trace elements, heavy metals in soil has long attracted both foreign and domestic scientists (Sola, 2003; Chibuike, 2014; Gil, 2004; Redondo-Gómez, 2009; Wyszkowski, 2017,2019; Shitova, 2005; Bakayeva, 2016; Stepanova, 2012; Firago, 2012). Most studies of deposit environments are carried out in urbanized areas with high technogenic load (Firago, 2012; Shitov, 2005), on domestic refuse landfill soils (Sola, 2003). Numerous studies have found that the level of minerals in the soil reflects the technogenic load on the territory and is transmitted in the system «soil - plant man» through products of plant origin. These include metal-processing waste, industrial emissions, fuel combustion products, automobile exhaust, pesticides, mineral and organic fertilizers, human settlements and others. Pesticides and heavy metals are persistent organic pollutants responsible for immune deficiency, certain types of cancer, and decreased length of pregnancy. (Bakary, 2019; Chibuike, 2014; Wyszkowski,2019; Firago, 2012; Shitov, 2005). Lead concentrations in the plant tissues had a linear and significant increase with the $\mathrm{Pb}$ concentration in the soils on domestic refuse landfill soils in Ibadan, Nigeria. Nevertheless, the concentrations of $\mathrm{Cd}$ in the leaves and roots were higher than concentrations in the stems except in the stem of plants grown on Aperin soil
(Sola, 2003). Ahmed K. Salama (2005) concluded that atmospheric deposition from urban and agricultural areas may play an important role in the enrichment of agricultural produce from $\mathrm{Cd}$ and/ or $\mathrm{Pb}$. Trace elements in soils may or may not enter the root tissues and then move to the xylem. Some are often transported to the leaves (e.g. $\mathrm{Zn}, \mathrm{Cd}, \mathrm{Co}, \mathrm{B}, \mathrm{Mo}$ ) whilst others (e.g. $\mathrm{Cr}, \mathrm{Pb}, \mathrm{Hg}$ and $\mathrm{Cu}$ ) typically have limited mobility to aerial parts of the plant (Giuffré, 2012). However, there is no comprehensive study on the character of accumulation, transition of trace elements and heavy metals from surface soil layers to plantbased products. Therefore, it becomes important to study the spectrum of chemical elements and to assess their level of content in comparison with their background concentrations in soil, as well as peculiarities of transition to aqueous soluble phase, accumulation by plants and transfer to plant-based products. Therefore, the purpose of this study is to determine the content of certain trace elements and heavy metals in soil, rhubarb, and its processed product - kvass made in different ways.

Similar studies to determine the level of toxic elements in veterinary supervision objects are being conducted in China, Poland, America and in many regions of Russia (Chibuike, 2014; Gil, 2004; Redondo-Gómez, 2009; Wyszkowski, 2017,2019). Lead $(\mathrm{Pb})$ and Cadmium $(\mathrm{Cd})$ concentrations in soils of four Ibadan landfill sites and a control site were determined in Nigeria. The accumulation of these heavy metals in the tissue of Amaranthus cruentus L. was also determined (Sola, 2003). In the Buenos Aires (Argentina) a studied of heavy metals occurrence in 33 urban and periurban soils dedicated to horticulture (Giuffré, 2012). The content of elements, including heavy metals, in a plant depends on many factors and their interactions. How ever, soil properties, which determine the bioavailability of these elements, are the main factor modeling the 
accumulation of elements in the plant (apart from its species). An increase in the accumulation of heavy metals is further linked to the mechanisms of plant physiology facilitating the uptake of elements under conditions of their deficiency in the soil (phosphorus and manganese in particular) (Różyło, 2017) In the Yaroslavl region (Russia), the character of air, water, soil contamination with pollutants and their ability to be accumulated in the human body are reflected in the works of Shitova E.V. (2005), Firago A.L. (2012), Stepanova M. V. (2012) and others. However, little attention is paid to the effect of antagonism and synergism of elements under conditions of polyelement environmental pollution, the migration capacity of metals, their cumulation in plant-based products. Thus, it is essential to study the character of contamination taking into account mutual influence of heavy metals and their migration.

The total concentration of heavy metals is one of the main indicators used in the study of chemical soil contamination. It is used in determining soil contamination both for comparison with background levels or maximum permissible concentrations and for determining the proportion of any form of heavy metal compounds. Increasing man-made environmental impact requires detailed studies of trace elements and heavy metals migration in biosphere components. The study of the behavior of technogenic-related heavy metals in soil is of great importance.

A number of authors have shown that the study of the total content of heavy metals in soil alone is not sufficient. Such studies may reflect the direction of some processes, such as heavy metal migration across biological chains. They differ in the form of location, mobility, bioavailability, and in-soil fixing mechanism, what defines the degree of their environmental hazard and requires a detailed study

An interesting and important issue is the study of a migratory capacity of heavy metals from soil to plant-based products. It depends on their mobility and toxicity to plants, soil properties that determine its buffering and protective capabilities Heavy metals have a different tendency to adsorption, so their toxicity to plant with the same contamination may be different (Stepanova, 2011). It is necessary to study the migration of trace elements and heavy metals along biological chains: soil - plants - plant-based products.

Human nutrition plays an important role in increasing life expectancy an maintaining efficiency. Healthy nutrition ensures good work of all internal organs and systems of human body contributing to prevention of diseases and premature aging. A successful solution to the problem of healthy nutrition depends on the development and introduction of the latest technologies based on natural plant materials with a high content of biologically active substances, functional ingredients and antioxidants. By now, there has been a growing interest in health maintaining, in a conscious and healthy nutrition. The human attitude to food as a medicine has created a demand for organic and the so called functional products. Healthy foods can help prevent disease and promote faster recovery. Now consumers view products not only as a means of satiety, but also as a means of preventing and treating diseases (Pozdnyakova, 2014). People fear sugar an chemicals - they are not trusted neither by Sweet'N Low, which is made of coal derivatives (saccharin), nor by Splenda from chlorinated sugar (sucralose). And while concepts such as «natural», «eco» and «organic» are blurred, most consumers are relactant to deal with artificial additives and toxic elements (Nepomniachtaya, Sidorova, 2014).

Foreign scientists of the last century paid attention to soft drinks subjecting them to comprehensive criticism. In 1997, in Nigeria, members of the Faculty of Chemistry of Obafemi Awolowo University became interested in the issue of increased heavy metal content in soft drinks. Preliminary studies identified levels of cobalt, copper, zinc, cadmium, lead, magnesium which were compared to maximum permissible levels (Nkono, 1997). In 1995, scientists from Australia took an interest in the definition of caffeine, benzoic acid, sorbic acid, artificial sugar substitutes (aspartame, saccharin, acesulfame potassium, alitame and dulcin) in soft drinks. They developed a quick method for determining the listed components and proved its high efficiency (Thompson, 1995).

Chemical and toxicological tests are a mandatory stage to confirm compliance of products with standardization documents and technical regulations. Manufacturers' compliance with Law No. 280 «On Organic Products and Amendments to Certain Legislative Acts of the Russian Federation» is mandatory for the production of high quality organic products (Bakary, 2019; L'uboš, 2018). Of particular value is the use of environmentally friendly raw materials by processing enterprises and the selection of technological modes of plant treatment for the least impact which may cause changes in the components of raw materials. Correction of technological modes towards the least impact contributes to preservation of valuable functional ingredients in the product while the intensity of migration of heavy metals remains an extremely urgent topic in organic production.

Food Technology Department scientists (Mumbai, India) note an increased interest in functional drinks based on milk, fruits, vegetables, legumes, grains, coffee and tea (Cheryl, 2018/19). Scientists of Krakow Agricultural University (Poland) studied the traditions of their country - to apply traditional technologies for the production of plant- based beverages which completely disappeared from the Polish market. Traditional bread kvass is noted to be a functional drink having consumer properties similar to commercial kvass (drinks made from malt concentrate) with a reduced (3 times) sugar content what makes it ideal for consumption to people of all ages (Gambuś, 2015). A number of scientists recognize value of plant raw material in the production of functional soft drinks. Whole grains contain a lot of nutrients and biologically active substances, so their regular use has a positive effect on human health (Cheryl, 2018/19). For many countries fermented soft drinks are traditional and each country has its own production characteristics. In Africa various traditional drinks made from sorghum have been found again which are of great socio-economic importance in human nutrition. Scientists at Abomey-Calavi University (Cotonou, Benin) note that traditional drinks have temporarily lost their position in a food market, but disappearance of many active synthetic substances in food has led to a renewed interest in natural ingredients (Konfo, 2015). Fermented products are one of the most popular drinks in the world with an obvious positive effect on overall health. All over the world they are traditional natural drinks with organic acids and vitamins low in calories (Solgajová, 2014). Scientists at the Faculty of Biotechnology and Food Sciences of Slovak Agricultural University (Nitra, Slovakia) proved that aside from being harmful for human health sucrose has a negative effect on the organoleptic and physico-chemical characteristics of fermented drinks (Bobková, 2013).

Therefore, in the course of the work a study of kvass was done, as this beverage has been one of the favorite national products in different countries since ancient times. Currently food industry offers many synthetic substitutes for kvass (kvass drinks) consisting of a carbon dioxide solution, sweeteners, flavorings, as well as kvass produced by traditional technology with the use of malt, rye, wheat or some other flour. A promising direction in the production of this drink is the use of rhubarb as a main raw material. It is worth emphasizing its special value as a natural environmentally friendly plant material.

\section{MATERIALS AND METHODS}

The study was conducted in 2019 - 2020 using an integrated approach - a combination of modern environmental, biochemical and statistical methods.

In total, samples 21 soil, 18 rhubarb, 15 kvass were collected. Soil sampling was carried out on the territory of the studied areas in the fall. The size of the combined site was $5 \times 5 \mathrm{~m}$ from a depth of $0-10 \mathrm{~cm}$. At least 5 point samples were taken from each site. To study soil contamination from transport highways, test sites were laid on roadside lanes taking into account the terrain, vegetation cover, meteo-hydrological conditions. Soil samples were taken from narrow lanes $200-500 \mathrm{~m}$ long at a distance of $0-10,10-50$ and $50-100 \mathrm{~m}$ from the road. One mixed sample consisted of 20-25 point samples. The mass of one point sample was $200 \mathrm{~g}$, and the mass of the combined sample was $1 \mathrm{~kg}$. The samples were dried and ground in a porcelain mortar. The ground sample was sifted through a sieve with a diameter of 1-2 mm, thoroughly mixed, leveled with a layer of 1.0 $1.5 \mathrm{~cm}$, the average sample was taken by quartering. The samples prepared (100 $\mathrm{cm}^{3}$ ) were transferred to the evaporation dish, 1-2 $\mathrm{cm}^{3}$ of concentrated nitric acid being added. The dish content was evaporated to wet salts. If the residue was dark, the acid treatment was repeated until it was clarified. Samples of the plant products were charred on an electric stove until smoke release ceased. They were then treated in a muffle oven. They were heated for 30 minutes to a temperature of $250{ }^{\circ} \mathrm{C}$ and held for 30 minutes. Then, the temperature was gradually increased every 30 minutes by $50{ }^{\circ} \mathrm{C}$ and adjusted to $460{ }^{\circ} \mathrm{C}$. If the ash was white, the study continued, if it was dark, the procedure was repeated. After that the sample was poured with electrolyte and treated in the instrument. The degree of contamination was evaluated by the content of gross, water-soluble and mobile forms of trace elements and toxic heavy metals. Assessment of soil chemical pollution level was carried out in accordance with the Methodological Recommendations for Atmospheric Heavy Metals Pollution Assessment in Settlements by Their Content in Snow and Soil, according to concentration factor of chemical substances in relation to the regional background and total contamination index.

A chemical concentration factor (CF) was used to estimate the level of soil chemical contamination, which is determined by the ratio of the actual content of an identified substance $(\mathrm{Ci})$ to the regional background $(\mathrm{Cb})$. It is calculated according to the formula: $\mathrm{CF}=\mathrm{Ci} / \mathrm{Cb}$. In addition, the total contamination index $(\mathrm{Zc})$ was calculated, which is determined by the formula $\mathrm{Zc}=\left(\mathrm{CFi}^{+} \ldots \ldots+\mathrm{CFn}\right)$ ( $\mathrm{n}-1)$, where $\mathrm{n}$ is a number of the identified summed substances; CFi concentration factor of the i-th contamination component.

The sample solutions were subsequently analyzed for heavy metal and trace element contents, as dry weight basis, using a Thermoelemental type Kvant-2AT atomic absorption spectrometer. Measurements were made using the hollow cathode lamps for $\mathrm{Cd}, \mathrm{Pb}, \mathrm{Cu}$, and $\mathrm{Zn}$ at the proper wavelength and the slit width were adjusted. The flame type used for all elements was air-acetylene.

The main components of the drink (plant material) were grown in Yaroslavl region according to the technology of organic production. The components for traditional non-alcoholic drinks were dry peppermint grass, lemon balm, red and black currant leaf, raspberry, rhubarb, sugar, water, yeast. An algebraic method was used to calculate the recipes. To speed up the calculation process, the inverse matrix method of Microsoft Excel spreadsheet processor was used. The drink formula is presented in Table 1. 
Table 1 Drink formula

\begin{tabular}{llcc}
\hline No. & Raw material & $\begin{array}{c}\text { Gross } \\
\text { weight, }\end{array}$ & Net weight, g \\
\hline 1 & Rhubarb & 150 & 142.5 \\
\hline 2 & Water & 1000 & 1000 \\
\hline 3 & Dry melissa leaves & 2 & 1 \\
\hline 4 & Dry peppermint leaves & 2 & 1 \\
\hline 5 & Dry black currant leaves & 2 & 1 \\
\hline 6 & Dry raspberry leaves & 2 & 1 \\
\hline 7 & Raisins & 5 & 3 \\
\hline 8 & Sugar & 100 & 100 \\
\hline 9 & Pure yeast cultures & 2 & 1 \\
\hline & Drink weight, g & & 1000 \\
\hline
\end{tabular}

In the course of the research two types of kvass production technology were studied - a technology with additional operation "rhubarb stems soaking" and "infusion of rhubarb stems with additional ingredients" and a technology with additional operation "cooking of rhubarb stems with additional ingredients" Technological modes of thermal and mechanical processing of plant material were developed with the aim of least impact on its components.

The data obtained were processed statistically on a personal computer using STATISTICA package, version 10.0. To test the reliability of differences between the two samples, Student and Fisher criteria were used, one-way and nonparametric ANOVA with the Kruskal -Wallis criterion being applied between several independent samples by single indicator. Both regression analysis and Spearman's rank correlation coefficient were used to clarify relationship between two or more samples. For all types of statistical analysis, a significance level of 0.05 was adopted.

The studies were carried out in urban and rural areas of the Yaroslavl region. The materials and sample size are presented in Table 2. Standard metal solutions for iron, copper, cadmium, lead, and arsenic were used for calibration. The error (sigma) of the method did not exceed $5 \%$.
Table 2 Examined materials

\begin{tabular}{lccc}
\hline & \multicolumn{3}{c}{ Number of, pcs. } \\
\cline { 2 - 4 } Examined object & Samples & repetitions & $\begin{array}{c}\text { metal } \\
\text { measurements }\end{array}$ \\
\hline Soil & 18 & 108 & 1944 \\
\hline Rhubarb & 6 & 18 & 324 \\
\hline Kvass & 6 & 18 & 324 \\
\hline Total: & 30 & 144 & 2592 \\
\hline
\end{tabular}

\section{RESULTS AND DISCUSSION}

In total, 21 soil samples were collected from a city (Zavolzhsky district, the city of Yaroslavl), a village (Tutaevsky district, Yaroslavl region) and «background» regions (Uglich district, Yaroslavl region $-1.5 \mathrm{~km}$ from the nearest road) to study the quantitative content of such trace elements, like zinc, copper, lead and cadmium, iron and arsenic. 2,592 quantitative atomic absorption measurements were done. All the soils were sandy or sandy loam soils.

According to the results of the research, the investigated elements in the areas examined were found to form the following decreasing row by the value of the average content in the water extract of the soil: iron> lead> zinc> copper> arsenic > cadmium.

In the study of soil contamination with microelements and heavy metals in all territories, MAC excess was not detected (table 3). Higher concentrations of zinc, iron, cadmium, lead and arsenic were identified in urban areas, copper being found in rural areas (Figs. 1 and 2). This is consistent with Sola et al.'s results (2003) who studied heavy metal pollution of various pot herbs (vegetables) in urban and peri-urban centers in Nigeria. Zubero Oleagoitia et al. (2008) noted higher levels of $\mathrm{Cd}$ and $\mathrm{Pb}$ in the resident population in urban areas caused by the constant consumption of crop products grown in the polluted urban areas.

Table 3 The content of the examined water-soluble mobile forms of metals in the soil, $\mathrm{mg} / \mathrm{kg}$

\begin{tabular}{|c|c|c|c|c|c|c|c|}
\hline \multirow[b]{2}{*}{ Area } & \multirow{2}{*}{$\begin{array}{l}\text { Distance from } \\
\text { the road (m) }\end{array}$} & \multicolumn{6}{|c|}{ Concentration } \\
\hline & & $\begin{array}{l}\text { Zink } \\
\mathbf{M} \pm \boldsymbol{\delta}\end{array}$ & Copper $M \pm \delta$ & $\begin{array}{r}\text { Iron } \\
\mathbf{M} \pm \boldsymbol{\delta}\end{array}$ & Cadmium $\mathbf{M} \pm \delta$ & $\begin{array}{l}\text { Lead } \\
\mathbf{M} \pm \boldsymbol{\delta}\end{array}$ & Arsenic $\mathbf{M} \pm \delta$ \\
\hline \multirow{3}{*}{ Village } & $0-10$ & $0.0046 \pm 0.0009^{*}$ & $0.0060 \pm 0.0014 *$ & $0.3146 \pm 0.0046^{*}$ & $0.0002 \pm 0.0000^{*}$ & $0.1257 \pm 0.0231 *$ & $0.0008 \pm 0.0001 *$ \\
\hline & $10-50$ & $0.0031 \pm 0.0006^{*}$ & $0.0033 \pm 0.0001$ & $0.2379 \pm 0.0001 *$ & $0.0017 \pm 0.0005$ & $0.0119 \pm 0.0001 *$ & $0.0007 \pm 0.0001 *$ \\
\hline & $50-100$ & $0.0026 \pm 0.0011$ & $0.0028 \pm 0.0003$ & $0.1580 \pm 0.0002 *$ & $0.0006 \pm 0.0001$ & $0.0103 \pm 0.0053$ & $0.0005 \pm 0.0001 *$ \\
\hline \multirow{3}{*}{ City } & $0-10$ & $0.0075 \pm 0.0005^{*}$ & $0.0034 \pm 0.0002 *$ & $0.7747 \pm 0.0023^{*}$ & $0.0015 \pm 0.0003^{*}$ & $0.2861 \pm 0.0112 *$ & $0.0076 \pm 0.0004 *$ \\
\hline & $10-50$ & $0.0061 \pm 0.0014 *$ & $0.0024 \pm 0.0011$ & $0.0028 \pm 0.0006^{*}$ & $0.0013 \pm 0.0003$ & $0.1420 \pm 0.0057^{*}$ & $0.0020 \pm 0.0005^{*}$ \\
\hline & $50-100$ & $0.0032 \pm 0.0008$ & $0.0021 \pm 0.0009$ & $0.4707 \pm 0.0132 *$ & $0.0005 \pm 0.0001$ & $0.0326 \pm 0.0073$ & $0.0012 \pm 0.0002 *$ \\
\hline \multicolumn{2}{|c|}{ BACKGROUND } & $0.0019 \pm 0.0001$ & $0.0007 \pm 0.0001$ & $0.1565 \pm 0.0001$ & $0.0003 \pm 0.0001$ & $0.0074 \pm 0.0003$ & $0.0001 \pm 0.0000$ \\
\hline \multicolumn{2}{|l|}{ MAC } & 23.0 & 3.0 & $* * *$ & $0.5^{* *}$ & 6.0 & $2.0^{* *}$ \\
\hline
\end{tabular}

Legend: * - differences between rural and urban areas are reliable $(\mathrm{p}<0.005), * *$ - standards for the gross content of the element are specified, $* * *$ - the standard is not set.

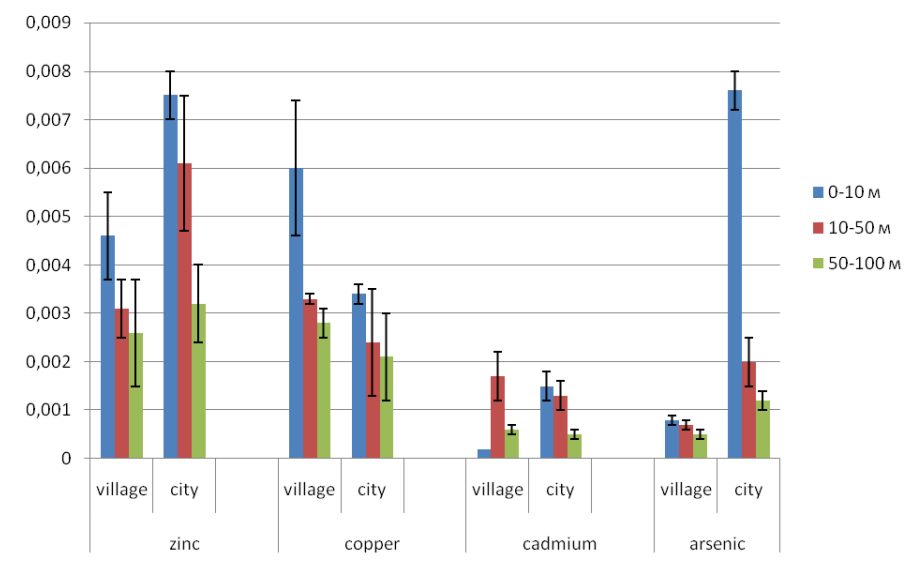

Figure1 The level of zinc, copper, cadmium and arsenic in the soil water extract in the areas examined.

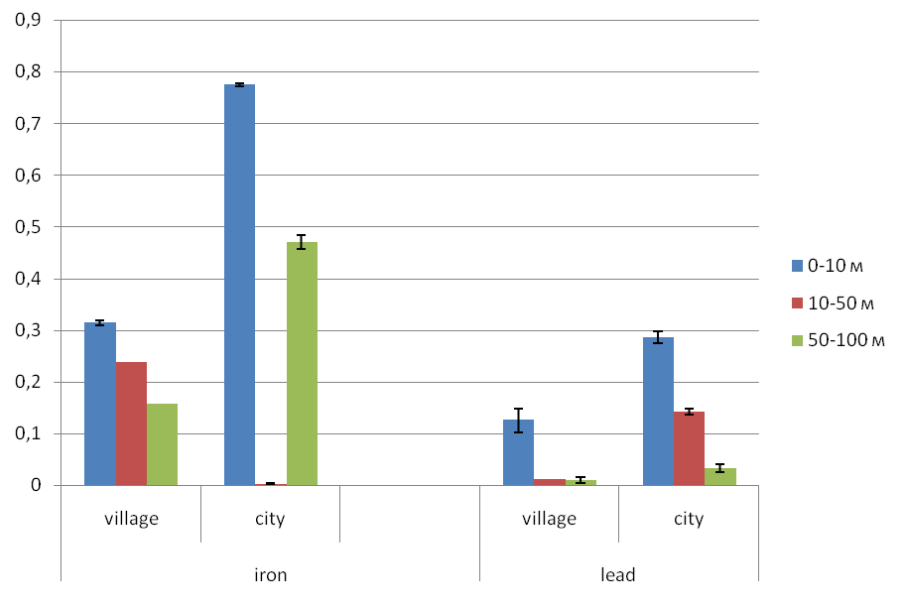

Figure 2 The level of iron and lead in the water extract of the soil in the areas examined. 
In terms of the total contamination index of water-soluble forms of heavy metals (Table 3), the soil examined in rural areas at a distance from the road of 50-100 $\mathrm{m}(\mathrm{Zc}=10.13)$ is the cleanest. It belongs to the category of soils with an acceptable level of contamination, which can be used for growing any crops. In rural areas, at a distance of 10-50 m from the road and the city - 50-100 meters soils are classified as fairly dangerous ( $\mathrm{Zc}=17.04$ and 20.81 respectively). These soils may be used for growing various crops provided that quality control is done. Monitoring of toxic substances in surface and ground waters should be done for such soils. At a distance of $10 \mathrm{~m}$ from the road of a rural settlement and 1-10, 10 $50 \mathrm{~m}$ of a big industrial city soils belong to areas with a highly dangerous level of contamination ( $\mathrm{Zc}=33.67 ; 127.33$ and 49.00 respectively). Here toxican accumulation in plants must be thoroughly controlled. The soils can be used for growing only industrial crops. It should be noted that the rural territory is characterized by a high content of copper, while the urban one is characterized by iron and arsenic. In both territories, there is an increased level of lead accumulation, the highest concentrations being observed along the road. The zinc content exceeds background values in the range from 1.36 to 3.94 times, iron from 1.37 to 4.95 times, copper from 2.94 to 8.57 times, cadmium from 0.67 to 5.57 times, lead from 1.39 to 19.19 times and arsenic from 5.0 to 76.00 times.

In order to verify the possible interdependent accumulation of metals in the soil, a correlation analysis was carried out, which revealed a strong feedback between lead and zinc, iron and copper, cadmium and lead, arsenic and iron $(\mathrm{r}=-0.94$; $0.98 ;-0.77$ and 0.99 , respectively; $\mathrm{p}<0.05$ ), strong line between cadmium and zinc, arsenic and copper $(r=0.92$ and 0.997 , respectively; $p<0.05)$, what proves literature data on the interconnected accumulation of these trace elements in the environment.

Table 4 The total index of soil contamination in the areas examined $(\mathrm{Zc})$

\begin{tabular}{|c|c|c|c|c|c|c|c|c|}
\hline \multirow{2}{*}{$\stackrel{\Xi}{\gtrless}$} & \multirow{2}{*}{$\begin{array}{l}\text { Distance from } \\
\text { the road }(\mathrm{m})\end{array}$} & \multicolumn{6}{|c|}{$\begin{array}{c}\text { Concentration factors } \\
\text { Microelements and Toxic Heavy Metals } \\
\end{array}$} & \multirow{2}{*}{$\begin{array}{c}\text { Total indicator } \\
\text { of pollution }\end{array}$} \\
\hline & & Zinc & Iron & Copper & Cadmium & Lead & Arsenic & \\
\hline \multirow{3}{*}{ Village } & $0-10$ & 2.43 & 2.01 & 8.57 & 0.67 & 16.99 & 8.00 & 33.67 \\
\hline & $10-50$ & 1.63 & 1.52 & 4.71 & 5.57 & 1.61 & 7.00 & 17.04 \\
\hline & $50-100$ & 1.37 & 1.37 & 4.00 & 2.00 & 1.39 & 5.00 & 10.13 \\
\hline \multirow{3}{*}{ City } & $0-10$ & 3.94 & 4.95 & 4.79 & 4.99 & 38.66 & 76 & 127.33 \\
\hline & $10-50$ & 3.19 & 3.98 & 3.47 & 4.17 & 19.19 & 20 & 49.00 \\
\hline & $50-100$ & 1.70 & 3.01 & 2.94 & 1.76 & 4.40 & 12 & 20.81 \\
\hline \multicolumn{2}{|c|}{ Background level } & 1.00 & 1.00 & 1.00 & 1.00 & 1.00 & 1.00 & 1.00 \\
\hline
\end{tabular}

Table 5 Correlation coefficients between the levels of element accumulation in the soil

\begin{tabular}{|c|c|c|c|c|c|c|}
\hline Element & Zinc & Copper & Lead & $\begin{array}{c}\text { Cadmi } \\
\text { um }\end{array}$ & Iron & Arsenic \\
\hline Zinc & & 0.0491 & $\begin{array}{c}- \\
0.9425 * \\
\end{array}$ & $0.9179 *$ & 0.1407 & -0.0190 \\
\hline Copper & 0.0491 & & 0.1902 & 0.4416 & $0.9794 *$ & $0.9974 *$ \\
\hline Lead & $\begin{array}{c}- \\
0.9425^{*}\end{array}$ & 0.1902 & & $0 . \overline{7} 09^{*}$ & -0.3592 & 0.2548 \\
\hline Cadmium & $0.9179^{*}$ & 0.4411 & $0.7709^{-}$ & & -0.2633 & 0.3785 \\
\hline Iron & 0.1407 & $\begin{array}{c}- \\
0.9794 * \\
\end{array}$ & -0.3592 & -0.2633 & & $\begin{array}{c}- \\
0.9887 * \\
\end{array}$ \\
\hline Arsenic & -0.0190 & 0.9974* & 0.2548 & 0.3785 & 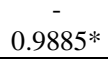 & \\
\hline
\end{tabular}

In analysis of transition and character of trace element accumulation in a soilplant system, there is a strong link between the level of $\mathrm{Pb}, \mathrm{Cd}$ in the soil and a plant $(\mathrm{r}=0.81$ and 0.71 ; respectively). This is consistent with Sola et al.'s findings (2003) that the concentration of lead in plant tissues increased linearly and significantly with an increase in the concentration of $\mathrm{Pb}$ in soils when studying heavy metal contamination of various pot herbs (vegetables) in urban and peri-urban centers in Nigeria. At the same time, Turner (1973) reported the level of $\mathrm{Cd}$ in plant tissues to be higher than in the soil, this being consistent with Sola et al.'s work (2003). In the course of the study we found a symbateness between the content of trace elements in the soil and rhubarb: a reliable very strong, close to functional, direct link between the level of $\mathrm{Zn}, \mathrm{Pb}$ and $\mathrm{Cu}(\mathrm{r}=$ $0.97 ; 0.90$ and 0.67 , respectively; at $\mathrm{p}<0.05$ ). When studying the crossenvironments transition of trace elements from soil to plants, a significant direct weak bond was established only for $\mathrm{Cu}(\mathrm{r}=0.31), \mathrm{Zn}(\mathrm{r}=0.33)$ and $\mathrm{Pb}(\mathrm{r}=0.35)$ In the raw material-product system, there is a reliable symbateness between the level of metal in kvass and the concentration in vegetable crops in terms of $\mathrm{Zn}(\mathrm{r}$ $=0.32), \mathrm{Cu}(\mathrm{r}=0.46)$ and $\mathrm{Cd}(\mathrm{r}=0.38)$. No other reliably significant links have been established. This indicates the synergy of trace elements coming from an environmental object and accumulating in living objects and transmitted through food chains. The revealed patterns support our hypothesis and literature - metals from the contaminated environment enter depositing environments through the air, a water-soluble form enters the plants, where they accumulate and are further transmitted through the food chain (Shitova, 2005). The results of studies obtained by Sola et al. (2003) and Salama (2005) also confirm the significance of heavy metal deposition from the air.

Table 6 Content of trace elements and heavy metals in the objects examined, $\mathrm{mg} / \mathrm{kg}$

Examined object

\begin{tabular}{lcccccc}
\cline { 2 - 6 } & Zinc $\mathbf{M} \pm \boldsymbol{\delta}$ & $\mathbf{C o p p e r} \mathbf{M} \pm \boldsymbol{\delta}$ & Iron $\mathbf{M} \pm \boldsymbol{\delta}$ & Cadmium $\mathbf{M} \pm \boldsymbol{\delta}$ & Lead $\mathbf{M} \pm \boldsymbol{\delta}$ & Arsenic $\mathbf{M} \pm \boldsymbol{\delta}$ \\
\hline Soil & $0.0031 \pm 0.0004$ & $0.004 \pm 0.0005$ & $0.2664 \pm 0.0002$ & $0.0016 \pm 0.0003$ & $0.0781 \pm 0.0048$ & $0.0005 \pm 0.0001$ \\
\hline Rhubarb & $21.1148 \pm 0.6831$ & $2.1874 \pm 0.0654$ & $25.8752 \pm 3.8308$ & $0.0049 \pm 0.0001$ & $0.0012 \pm 0.0001$ & $0.0203 \pm 0.0001$ \\
\hline
\end{tabular}

The analysis of migration ability of elements in the «soil-plant-plant-based products» system demonstrated poor migration ability for zinc and iron. Salama and Radwan (2005) also reported zinc levels to be typically below safe limits. However, according to Różyło, K. et al.'s studies (2017) zinc concentrations in the examined plant products were significantly higher than in the soil. This was the element that accumulated the most.
The results of identification of heavy metals and trace elements in kvass produced by two technologies: 1 - technology with additional operation «soaking of rhubarb stems» and «infusion of rhubarb stems and additional ingredients» and 2 - technology with additional operation «cooking of rhubarb stems and additional ingredients» are presented in Tables 7 and 8 .

Table 7 Macro- and microelements content in the kvass

\begin{tabular}{|c|c|c|c|c|c|}
\hline \multirow{2}{*}{$\begin{array}{l}\text { Macro-/ } \\
\text { microelement, } \\
\mathrm{mg} / \mathrm{l}\end{array}$} & \multicolumn{2}{|c|}{ Test results } & \multirow{2}{*}{$\begin{array}{l}\text { Recommended daily } \\
\text { intake, mg }\end{array}$} & \multicolumn{2}{|c|}{$\begin{array}{c}\text { Content from the recommended daily intake in a single } \\
\text { serving }(237 \mathrm{ml}), \%\end{array}$} \\
\hline & 1 & 2 & & 1 & 2 \\
\hline$\overline{\mathrm{Zn}, \mathrm{mg} / \mathrm{l}}$ & 0,10 & 0,15 & $10 \ldots 15$ & 0,237 & 0,356 \\
\hline$\overline{\mathrm{Cu}, \mathrm{mg} / \mathrm{l}}$ & 0,08 & Traces & 2 & 0,948 & - \\
\hline$\overline{M n}, \mathrm{mg} / \mathrm{l}$ & 0,106 & 0,084 & $5 \ldots 10$ & 0,502 & 0,398 \\
\hline$\overline{\mathrm{Fe}}, \mathrm{mg} / \mathrm{l}$ & 0,69 & 1,97 & $10 \ldots 18$ & 1,635 & 4,67 \\
\hline $\mathrm{K}, \mathrm{mg} / \mathrm{l}$ & 0,56 & 0,79 & $3000 \ldots 5000$ & 0,004 & 0,006 \\
\hline$\overline{\mathrm{Mg}, \mathrm{mg} / \mathrm{l}}$ & 0,23 & 0,29 & $400 \ldots 500$ & 0,013 & 0,017 \\
\hline $\mathrm{Ca}, \mathrm{mg} / \mathrm{l}$ & 0,085 & 0,085 & $500 \ldots 1000$ & 0,004 & 0,004 \\
\hline
\end{tabular}


Table 8 Results of the toxicology study of the kvass

\begin{tabular}{|c|c|c|c|}
\hline \multirow{2}{*}{ Indicator } & \multicolumn{2}{|c|}{ Test results } & \multirow{2}{*}{ Acceptable level } \\
\hline & 1 & 2 & \\
\hline Lead & less than $0,02 \mathrm{mg} / \mathrm{kg}$ & less than $0,02 \mathrm{mg} / \mathrm{kg}$ & not more than $0,3 \mathrm{mg} / \mathrm{kg}$ \\
\hline Arsenic & less than $0,001 \mathrm{mg} / \mathrm{kg}$ & less than $0,001 \mathrm{mg} / \mathrm{kg}$ & not more than $0,1 \mathrm{mg} / \mathrm{kg}$ \\
\hline Cadmium & less than $0,005 \mathrm{mg} / \mathrm{kg}$ & less than $0,005 \mathrm{mg} / \mathrm{kg}$ & not more than $0,03 \mathrm{mg} / \mathrm{kg}$ \\
\hline Mercury & less than $0,0002 \mathrm{mg} / \mathrm{kg}$ & less than $0,0002 \mathrm{mg} / \mathrm{kg}$ & not more than $0,005 \mathrm{mg} / \mathrm{kg}$ \\
\hline
\end{tabular}

The research results revealed slight variations in the content of basic macro - and microelements in the kvass produced according to the technology 1 compared to the kvass, made according to the technology 2. Moreover, the technology that includes the additional operation «boiling rhubarb stalks and additional ingredients» provided the greatest extraction of functional ingredients from the raw material into the finished product. The consumption of a single serving of $237 \mathrm{ml}$ of the kvass will satisfy the daily recommended allowance of zinc for $0,356 \%$, iron for $4,67 \%$, potassium for $0,06 \%$ and magnesium for $0,017 \%$ for an adult.

The data presented in tables 6 allow us to conclude that the quality indicators of the kvass made from natural vegetable raw materials correspond to Technical Regulation of the Customs Union TR CU 021/2011 «On food safety», GOST 28188-2014 «Non-alcoholic drinks», GOST 31494-2012 «Kvases. General specifications».

\section{CONCLUSION}

The results of the studies showed that the level of copper and lead in soils in rural areas is considerably higher than in the city. The concentration of cadmium and zinc is higher in the urbanized area. In the soils of rural and urbanized areas, the concentration of all the metals studied is sure to be higher than in the background levels. This indicates that soil contamination is caused not only by natura presence of elements but anthropogenic pollution as well. The studies revealed a symbateness between the content of elements in the environments, raw materials and products processed, thus confirming the ability of trace elements and heavy metals to accumulate and migrate through biological chains in a water-soluble form.

Plant material produced according to organic production principles and the processing technology we've developed contribute to both the least impact on its constituent parts and the increased macro- and microelements content, the content of toxic elements remaining within the limits of the existing regulatory documents.

Acknowledgement: Slovak University of Agriculture in Nitra, Slovak Republic; FSBEI HE Yaroslavl SAA, Yaroslavl, Russia

\section{REFERENCE}

Bakary, T., Flibert, G., Bernadette, S. P., Oumarou, Z., François, T., Cheikna, Z. Aly, S. (2019). Evaluation of heavy metals and pesticides continents in market gardening products sold in some principal markets of Ouagadougou (Burkina

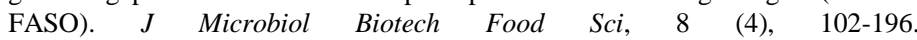
http://dx.doi.org/10.15414/jmbfs.2019.8.4.1026-1034

Bakayeva, E.A. (2016). Impact of Environmental Factors on Microelement Status of Newborns and Children of Pre-School Age Under Conditions of the European North and the Central Russia: Thesis for the Degree of Candidate of Biological Sciences/National Research Novgorod State University named after N.I. Lobachevsky, 200. https://www.elibrary.ru/item.asp?id=30438647

Bobková, A., Kunová, S., Bobko, M., Zeleňáková, L., Lopašovský, L., Melounová, A. (2013). Effekt of addition of saccharose to the sensory properties of beer. J Microbiol Biotech Food Sci, 2, 2238-2248. https://www.jmbfs.org/wpcontent/uploads/2013/06/116_jmbfs_bobkova_fbp_f.pdf

Cheryl, G. Fernandes, Sachin K. Sonawane, Arya, S. S. (2018/19). Cereal based functional beverages: a review. J Microbiol Biotech Food Sci, 8 (3), 914-919. http://dx.doi.org/10.15414/jmbfs.2018-19.8.3.914-919

Chibuike, G. U., Obiora, S. C. (2014) Heavy Metal Polluted Soils: Effect on Plants and Bioremediation Methods. Hindawi Publishing Corporation Applied and Environmental Soil Science Volume, Article ID 752708, 12 pages http://dx.doi.org/10.1155/2014/752708

Firago, A.L. (2012) Content of heavy metals in biosubstrates of children from 1 to 3 years old living under anthropogenic load (on the example of the Yaroslav region): thesis for the degree of Candidate of Biological Sciences. Nizhny Novgorod State University named after N.I. Lobachevsky, 200. https://www.elibrary.ru/item.asp?id=30362026

Gambuś, H., Mickowska, B., Bartoń, H., Augustyn, G., Zięć, G., Litwinek, D....Berski, W. (2015). Health benefits of kvass manufactured from rye wholemeal bread. J Microbiol Biotech Food Sci, 4 (special issue 3), 34-39. http://dx.doi.org/10.15414/jmbfs.2015.4.special3.34-39

Gil, C., Boluda, R., Ramos, J. (2004) Determination and evaluation of cadmium, lead and nickel in greenhouse soils of Almería (Spain). Chemosphere, 55 (7), 1027-1034. https://doi.org/10.1016/j.chemosphere.2004.01.013
Giuffré, L., Romaniuk, R. I., Marbán, L., Roós, R. P., Garcaí Torres, T. P. (2012) Public health and heavy metals in urban and periurban horticulture. Emir. J. Food Agric., 24 (2),148-154. http://ejfa.info/

Harangozo, L', Šnirc, M., Árvay, J., Bajčan, D., Bystrická, J., Trebichalský, P... Jančo, I. (2018). The heavy metal continents in selected kind of spices. $J$
Microbiol
Biotech
Food
Sci,
(2),760-764.

http://dx.doi.org/10.15414/jmbfs.2018.8.2.760-764

Konfo, Ch. Tétédé Rodrigue, Chabi, N. W., Dahouenon-Ahoussi, E., CakpoChichi, M., Soumanou, M.M., Sohounhloue, D. Coco Kodjo. (2015) Improvement of African traditional sorghum beers quality and potential applications of plants extracts for their stabilization: a review. J Microbiol Biotech Food Sci. 5 (2), 190-196. http://dx.doi.org/10.15414/jmbfs.2015.5.2.190196

Nepomnyashchaya, A. A., Sidorova, E. Yu. (2014). Programs of social nutrition and food support in Russia and the USA: analysis and comparison of communication prospects: materials of scientific student conference (results of scientific work of students in 2013-2014),

112 . https://www.elibrary.ru/item.asp?id=24161882

Nkono, N. A., Asubiojo, O. I. (1997) Trace elements in bottled and soft drinks in nigeria - a preliminary study, the science of the total environment. Elsevier Science Publishing Company, T. 208. № 3, 161-163. http://dx.doi.org/10.1016/s0048-9697(97)00289-1

Pozdnyakova, V., Senchenko, M., Latysheva, O., Makhova, N., Olenchuk, E., Belova, I. (2019). Production of a mors drink with a natural sweetener, stevia [Stevia rebaudianabertoni (L.)]: Book of abstracts of the 14th International Scientific Conference organized by the Faculty of Biotechnology and Food Sciences, 63-64.

https://drive.google.com/file/d/1MLm2wykDfkKChJpxER0tqimUtgOR5tmq

Pozdnyakova, V., Senchenko, M., Latysheva, O., Makhova, N., Olenchuk, E. Belova, I. (2019). Production of a mors drink with a natural sweetener. Agricultural research and technology, 23 . issue 1, 253-256. http://dx.doi.org/10.19080/ARTOAJ.2019.23.556222

Redondo-Gómez, S., Cantos, M., Mateos-Naranjo, E., Figueroa, M. Enrique, Troncoso, A. Heavy (2009) Metals and Trace Element Concentrations in Intertidal Soils of Four Estuaries of SW Iberian Peninsula. Soil and Sediment Contamination: An International Journal, $18 \quad$ (3), 320-327. https://doi.org/10.1080/15320380902772646

Różyło, K. et al. (2017) Phytochemical properties and heavy metal accumulation in wheat grain after three years' fertilization with biogas digestate and mineral waste. Agricultural and food science, 26, 148-159. DOI: https://doi.org/10.23986/afsci.63156

Salama, A. K., Radwan, M. A. (2005) Heavy metals (Cd, Pb) and trace elements $(\mathrm{Cu}, \mathrm{Zn})$ contents in some foodstuffs from the Egyptian market. Emir. J. Agric. Sci.,17 (1), 34-42. http://www.cfa.uaeu.ac.ae/Research/EJAS.htm

Shitova, E.V. (2005). Content of heavy metals in biosubstrates of children under conditions of industrial city: auto abstract of thesis for the degree of Candidate of Biological Sciences. Yaroslav State University named after P.G. Demidov. 19 https://www.elibrary.ru/item.asp?id=15822950

Sola, O., Rasheed, O. Awodoyin, Opadeji, T. (2003) Urban agricultura production: heavy metal contamination of Amaranthus cruentus L. grown on domestic refuse landfill soils in Ibadan, Nigeria. Emir. J. Agric. Sci., 15 (2): 87 94. http://www.cfs.uaeu.ac.ae/research/ejas.html

Solgajová, M., Ivanišová, E., Nôțková, J., Frančáková, H., Tóth, Ț., Dráb, Š (2014). Antioxidant activity and polyphenol content of malt beverages enriched with bee pollen. J Microbiol Biotech Food Sci, 3 (special issue 3), 281-284 https://ru.scribd.com/document/211905300/Effect-of-Temperature-on-the-

Process-of-Beer-Primary-Fermentation

Thompson, C. O., Trenerry, V. C., Kemmery, B. (1995) Micellar electrokinetic capillary chromatographic determination of artificial sweeteners in low-joule soft drinks and other foods. Journal of chromatographya : Elsevier Science Publishing Company, T. 694. № 2,507-514. http://dx.doi.org/10.1016/00219673(94)01224-3

Turner, M. A. (1973). Effect of Cadmium treatment on Cadmium and Zinc uptake by selected vegetable species. J. Environ. Qual., 2, 118-119. https://doi.org/10.2134/jeq1973.00472425000200010020x

Wyszkowski, M., Modrzewska, B. (2017) Effect of neutralising substances on the total content of trace elements in soil contaminated with zinc. J. Elem., 22(4) 1439-1451. https://doi.org/10.5601/jelem.2017.22.1.1409

Wyszkowski, M. (2019) Soil Contamination with Copper and its Effect on Selected Soil Properties After Applying Neutralizing Substances. Pol. J. Environ Stud., 28(4), 2465-2471. https://doi.org/10.15244/pjoes/90357 
Zubero Oleagoitia, M. B. et al. (2008). Metales pesados ( $\mathrm{Pb}, \mathrm{Cd}, \mathrm{Cr}$ y $\mathrm{Hg}$ ) en població $\mathrm{n}$ general adulta pró xima a una planta de tratamiento de residuos urbanos de Bizkaia. Rev. Esp. Salud Publica., 82, 481-492. https://www.mscbs.gob.es/biblioPublic/publicaciones/recursos_propios/resp/revis ta cdrom/vol82/vol82 5/RS825C 481.pdf 